\title{
A centre for community life in its fullness
}

\begin{tabular}{|c|c|}
\hline $\begin{array}{l}\text { Author: } \\
\text { Attie van Niek }\end{array}$ & $e^{1}$ \\
\hline $\begin{array}{l}\text { Affiliation: } \\
{ }^{1} \text { Department } \\
\text { Religion and } \\
\text { University of } \\
\text { South Africa }\end{array}$ & $\begin{array}{l}\text { Science of } \\
\text { Aissiology, } \\
\text { retoria, }\end{array}$ \\
\hline $\begin{array}{l}\text { Corresponden } \\
\text { Attie van Niek }\end{array}$ & $\begin{array}{l}\text { ice to: } \\
\text { erk }\end{array}$ \\
\hline $\begin{array}{l}\text { Email: } \\
\text { attievannieker }\end{array}$ & k@nova.org.za \\
\hline $\begin{array}{l}\text { Postal addres } \\
\text { PO Box } 38465 \\
\text { South Africa }\end{array}$ & s: \\
\hline $\begin{array}{l}\text { Dates: } \\
\text { Received: } 11 \text { n } \\
\text { Accepted: } 28 \\
\text { Published: } 09\end{array}$ & $\begin{array}{l}\text { Mar. } 2015 \\
\text { July } 2015 \\
\text { Sept. } 2015\end{array}$ \\
\hline $\begin{array}{l}\text { How to cite th } \\
\text { Van Niekerk, } \\
\text { centre for con } \\
\text { in its fullness', } \\
\text { Ecclesia } 36(3) \text {, } \\
7 \text { pages. http: } \\
\text { org/10.4102/ }\end{array}$ & $\begin{array}{l}\text { lis article: } \\
\text { A., 2015, 'A } \\
\text { nmunity life } \\
\text { Verbum et } \\
\text { Art. \#1448, } \\
\text { //dx.doi. } \\
\text { Je.v36i3.1448 }\end{array}$ \\
\hline $\begin{array}{l}\text { Note: } \\
\text { This article rep } \\
\text { theological ref } \\
\text { Faculty Resear } \\
\text { of the Faculty } \\
\text { University of P } \\
\text { Ecodomy - Life } \\
\text { The theme is } \\
\text { the perspectiv } \\
\text { theological dis } \\
\text { A conference } \\
\text { was held on } 2 \\
2014 .\end{array}$ & $\begin{array}{l}\text { lection on the } \\
\text { ch Theme (FRT) } \\
\text { of Theology, } \\
\text { retoria, entitled } \\
\text { in its fullness. } \\
\text { ortrayed from } \\
\text { e of various } \\
\text { ciplines. } \\
\text { on this theme } \\
7-28 \text { October }\end{array}$ \\
\hline $\begin{array}{l}\text { Copyright: } \\
\text { (c) 2015. The } \\
\text { Licensee: AOS } \\
\text { OpenJournals } \\
\text { licensed unde } \\
\text { Commons Att } \\
\text { License. }\end{array}$ & $\begin{array}{l}\text { Authors. } \\
\text { IS } \\
\text { This work is } \\
r \text { the Creative } \\
\text { ribution }\end{array}$ \\
\hline Read online: & \\
\hline 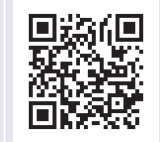 & $\begin{array}{l}\text { Scan this QR } \\
\text { code with your } \\
\text { smart phone or } \\
\text { mobile device } \\
\text { to read online. }\end{array}$ \\
\hline
\end{tabular}

This article considers some theological reasons why there is a Centre for Sustainable Communities at the Faculty of Theology, University of Pretoria. The role of the Centre is discussed within the global and local search for sustainability; the world-wide trend in churches towards a missional approach, which emphasises the church's life-giving role in all areas of life, and the theological reflection on the relationship between the church community and the civil community, so reflecting on the role of the local church to promote life in its fullness in the community. The Centre for Sustainable Communities (Centre) was established at the Faculty of Theology, University of Pretoria, in 2014. The Centre is intended to develop resources for local congregations to promote life in its fullness in local communities in southern Africa in an effective and meaningful way. In this article attention is given to the theological reasons for its establishment and where it is being positioned in the wider field of sustainability institutions. Attention will be given to the following:

- The position of the Centre in the global search for sustainability.

- Life in its fullness in the emerging 21st century missional paradigm.

- The Christian community as agent of life in its fullness in the civil community.

\section{Introduction}

\section{The position of the Centre in the global search for sustainability}

The term 'sustainable communities' forms part of a field of meaning that includes related terms such as sustainable living, sustainable society, eco-cities, green cities, sustainable cities, sustainable development, sustainable agriculture, sustainable homes, sustainability in mining, and sustainable clothing.

Both terms, sustainable and community have a wide range of meanings and need to be defined. As can be expected, the terms take on various ideological shades and shapes, depending on where each version originated and for what purpose, no less so when they are combined.

With the Centre for Sustainable Communities it is no exception. This article aims to shed more light on the theological arguments for having such a centre at a faculty of theology.

\section{Programmes at academic institutions that focus on sustainability}

The terms 'sustainable society' and 'sustainability' (but not 'sustainable development') were introduced into the present world-wide discourse by the World Council of Churches in 1974. Prior to that, the term 'sustainability' referred to, for example, the sustainable yield of forests and fisheries (Rasmussen 1996:138).

Today, there are many programmes that attend to sustainability all over the world. In South Africa, for example, the University of the Witwatersrand has the Centre for Sustainability in Mining and Industry (CSMI), which is part of the School of Mining Engineering. The University of the Free State has the Centre for Sustainable Agriculture, Rural Development and Extension, in the Faculty of Natural and Agricultural Sciences. At the University of Cape Town, the Environmental and Geographical Science Department offers an MPhil Degree in Environment, Society and Sustainability and a Masters course in Climate Change and Development which 'provides an interdisciplinary training in climate change and sustainable development, with a specific focus on the issues of relevance to African development' (http://www.egs.uct.ac.za/degree. $\mathrm{html}$ ). These few random examples show that sustainability is widely seen as an important goal to pursue in diverse sectors and contexts. In some overseas countries there are extensive programmes focusing on sustainability and related issues such as the corporate responsibility of businesses. 
All these initiatives are part of a bigger picture. They are all interdependent. All the sectors of society are interlinked, and no one can be completely sustainable without the others. Mines, for example, can pollute the water that communities depend on, and social unrest can cause the mines to close down. In an interview, Nancy Coulson of the CSMI (see above), that is working on sustainability in mining, said:

\begin{abstract}
... the CSMI collaborates with research groups ... to tap into the methods used in working with communities and the institute's body of knowledge on how communities in South Africa are shaped ... We do this because, while there are natural limits to what you can extract from nature, that's not the only important aspect of sustainability. We also need to talk about a sustainable society, sustainable communities and sustainable business models. (Zhuwakinyu 2013:1)
\end{abstract}

This tendency to relate sustainability in one sector to sustainability in other sectors occurs globally, as can be seen in the report by Daniel M. Franks, et al.: Conflict translates environmental and social risk into business costs (2014:2-4). Daniels is from the Centre for Social Responsibility in Mining, which is one of six research centres at the Sustainable Minerals Institute of the University of Queensland, Brisbane. The report investigates 50 cases world-wide. The authors come from various countries such as the USA, England and Peru.

The report of Franks and his colleagues has calculated the business costs of social risk. This calculation is important to convince businesses that they do not only have a social responsibility, which can be seen, from a business perspective, as a soft issue, a 'nice to have', or as a way of building a positive corporate image. The report indicates clearly that social risk is a much harder business concern, which can make the difference between good and bad performance or could even be a matter of survival. This is an example of the interdependence of businesses, authorities and communities, including low income communities (Franks et al. 2014:1, 6-7).

In a similar way, there are hard reasons why each role player should get involved with others in the search for sustainability. The Centre will focus on the role of the church and the community within the bigger context.

\section{The basic concepts sustainable development and sustainable communities}

On the one hand, the different initiatives globally that search for sustainability are interdependent; on the other hand, they are divided by factors such as language, ideology and the way that our academic tradition structures the various academic disciplines.

Perhaps the most fundamental difference is described by Rasmussen (1996:135) as follows: 'The notion of sustainable development maintains the basic assumption that development depends on a continuous growth in production'. This connection between production and development has led to the two simple categories, 'developed' and 'underdeveloped', with which the thousands of cultures in the world have been placed on a single progressive track. Those who are underdeveloped should catch up with those who are developed. This way of thinking has become common since President Harry Truman of the USA introduced the development era in a speech in 1949.

If the qualification 'sustainable' is added to the basic premise of development, the issue is 'how to alter environments to serve the economy and yet be sustained'. The idea of development as a continuous growth in production and consumption is maintained, with the added notion that it must be growth that nature can sustain. Both growth and the biosphere are regarded as 'sustainable' (Rasmussen 1996:136, 137).

In an alternative approach that has a long tradition and has been gaining momentum in recent years, the issue is 'how to alter economies so as to serve comprehensive environments ordered around healthy communities'. The idea of development is now linked to concepts other than continuously growing production and consumption; the focus is now on local and regional communities attending to '... home environments in a comprehensive way around basic needs and quality of life' and on 'mutually enhancing earth relations' (Rasmussen 1996:137).

One of the differences between these two approaches, says Rasmussen (1996:137), is that the former approach views the world as 'sets of industrial and information systems that need to be managed globally'. That leads to pretentious questions, exemplified by the questions of William C. Clark in an article, 'Managing the Planet' in Scientific American: 'What kind of planet do we want? ... How much species diversity should be maintained in the world? ... How much climate change is acceptable?' The alternative approach 'neither pretends such reach nor assumes such a posture'.

The Centre for Sustainable Communities tends towards the alternative approach. We need to find local concepts of development that do not merely bring continuous growth in present patterns of production and consumption, when we have already surpassed the capacity of the planet to provide resources for our present global economic order and absorb the waste produced by it. In the search for such a concept, relationships on the local level will play an important role.

The quest for sustainability confronts communities with difficult issues. Both affluent and poor communities have their particular issues to confront. They display different processes of change and patterns of connections, but both have unsustainable patterns of living. They also interact with each other and have, in this process, different roles to play and responsibilities to shoulder. For both, it appears, the question can only to a certain level be solved by greater efficiency. In a WCC paper, Accelerated climate change; sign of peril, test of faith, it is stated:

$[w]$ e are pushed to go beyond efficiency, renewable energy technologies and individual lifestyle changes to the formidable 
task of reconceiving and transforming the economic system. This task belongs within the context of a renewed vision of community. (Quoted by Rasmussen 1996:144)

The same theme is picked up by the South African Council of Churches:

It is a matter of moral vision. We need to envision alternatives to the current global economic order that has caused climate change. Such a vision needs to be attractive enough to motivate millions of people, to energise and mobilise action. The question is therefore whether a different world is indeed possible. (Declaration SACC 2009, p ix, 41)

\section{Life in its fullness in the emerging 21st century missional paradigm}

The emerging missional approach is in several ways different form the paradigm that is associated with the term missionary. Some of these differences are: in the missionary movement, the church sends a missionary to someplace else to, primarily evangelise people and plant a church. In the missional movement, the congregation itself is sent to its own community or communities to help restore all relations: the relation to God, the relations between people and the relation to the ecology, which in theological language is the creation of God.

'Relations' is a key concept in the missional approach and in contemporary theology. In fact, over the last century, a broad consensus has developed in Western theology and philosophy that human personhood is fundamentally constituted by its relationships. Eberhard Jüngel calls sin 'the urge towards relationlessness and dissociation' and the sinner 'a person without relations' (Jenson 2006:1-2). It is a concept that can be helpful in the search for sustainability, and that can form a bridge between theological language and the general discourse on sustainability.

'Sin' is an important concept in the Christian message. It indicates what is wrong in the world, and what we are saved from by believing in Christ. Jenson argues that the image of being 'curved in on oneself' is the best paradigm for understanding sin relationally. It provides a conceptual umbrella under which various features of a relational account of sin can be gathered. He also tests the applicability of the paradigm against various acts that have been regarded as sin in the Christian tradition (Jenson 2006:5, 130-131). This view is very relevant for describing the role of the church in the search for sustainability: sin, which is a central concept in church life, is here seen in terms of all the relations we are involved in, also in the community and with the ecology: withdrawing from relations, or unhealthy and unjust relations, are sin. The Christian faith is expressed in relations marked by love and justice.

Karl Barth demonstrated how the concept of turning into oneself can help us to understand the dysfunctionalities of daily life. He mentioned three forms of sin: pride (where we live according to our own will), sloth (where we see, or even experience need and injustice but have no response and take no effort to put things right) and falsehood (where we exercise an opinion that does not engage with the context at hand). All three '... are characterized first and foremost by broken relationships in which people live for themselves rather than for God and others' (Jenson 2006:131). With these examples Barth helps the church and theology to understand its role in the search for a sustainable society in a realistic way, and according to its own identity: by restoring healthy relationships, also with the ecology. These three forms of sin, and also ways of being concerned with yourself that are damaging to the ecology and to others, are clearly recognisable in our society, even in the church, and they may go a long way to explain the conditions in society that are not sustainable, or humane, or just.

The same approach is described in positive terms in the theme wholeness of life or life in its fullness. This theme, with related terms such as life-affirming and life-giving relations, practices and ministries, has been a central theme in many church circles in the world over the last number of years. Lifegiving theology is the motto of the Faculty of Theology at the University of Pretoria. And the General Synod of the Dutch Reformed Church of 2013 accepted a document on the mission of the church which stated that a missional congregation is called to restore relationships in a broken world and to live according to God's plan for his creation (Algemene Sinode 2013:9). This policy document resonates with documents in churches in the rest of the world, over a broad spectrum, such as the document Together towards life in the Resource Book of the World Council of Churches of 2013, documents of the Roman Catholic Church such as the encyclicals Caritas in veritate (Pope Benedict XVI 2009) and Laudato Si', On care for our common home (Pope Franciscus 2015), and documents such as Balia and Kim (2010), Edinburgh 2010, Volume II: Witnessing to Christ Today.

The emphasis on relations and responsibility finds practical support in the principle of subsidiarity, which plays an important role in Roman Catholic circles. Subsidiarity means that one should not withdraw from individuals and commit to the community what they can accomplish by their own enterprise and industry. The principle was described by Pope Pius XI in 1931. This principle leads to an emphasis on grassroots community projects where community members are involved in leadership and decision-making (cf. Rasmussen 1996:336). At the same time, those functions that cannot be executed on a local level must be escalated to higher levels: '... subsidiarity asks not for the most local but for the most appropriate level of organization and response' (Rasmussen 1996:339).

These trends in the church and in theology provide the framework in which the Centre for Sustainable Communities at the Faculty of Theology has come into existence. The Centre exists in order to understand and promote the type of relationships - to God, to people, to nature - that would make it sustainable, whole, humane, just - in a realistic and not a utopian way. 


\section{The Christian community as agent of life in its fullness in the civil community}

To what extent should the church link up with the aspirations and achievements of our communities, and to what extent should we present resistance, criticism, and an alternative way of living?

The tradition that the Christian community should be involved in the secular community in a constructive and in a critical manner goes back to the Old Testament, and this line can be traced through the centuries. A few examples are mentioned below.

The Old Testament emphasises the distinction between the community that belongs to God and other communities, but it is also said, from the beginning, that all things that exist were created by God, and that this creation was 'very good' (Gn 1), and that Abram was called so that all nations could be blessed through God's history with Israel (Gn 12).

Christopher Wright, an Old Testament scholar from the evangelical tradition, emphasises that the people of Israel were called to be a blessing to the nations, and this calling began with their ethical quality of life as a community:

... ethics stands as the mid-term between election and mission. Ethics is the purpose of election and the basis of mission ... the ethical quality of life of the people of God is the vital link between their calling and their mission. God's intention to bless the nations is inseparable from God's ethical demand on the people he has created to be the agent of that blessing. There is no biblical mission without biblical ethics. (Wright 2010:93, 94)

This alternative way of living was intended to become reality in the Promised Land, where the people of God had to live in a way that was different from other nations. However, they often failed to do so, and found themselves in other countries, where they were unable to live their own lives as community. In these cases, they often loyally served the foreign government and promoted life - as was the case with Joseph and Daniel. Daniel behaved in accordance with the letter that Jeremiah sent to the exiles in Babylon, of which Daniel was one. In Daniel 9:2 there is a reference to the scriptures of Jeremiah, and the behaviour of Daniel corresponded with the advice of Jeremiah: 'Seek the peace and prosperity (šalom) of the city to which I have carried you into exile'. Wright (2010) comments:

Šalom ... goes beyond peace as the absence of conflict or war, to all-round welfare or well-being. It speaks of wholeness of life that the Old Testament included in the blessing of God as the fruit of covenant faithfulness. It really is remarkable that Jeremiah urges the exiles to seek such blessing for their Babylonian neighbours. (pp. 230-231)

Daniel brought the message of God's punishment to the king of Babylon, but he also tried to help the king to find the right way, that would save him from this punishment - seeking the peace of the city.
The tradition is continued in the New Testament, where Paul speaks in Romans 13:3 and 6 of the Roman governing authorities as 'God's servants', 'using words otherwise used for Christian ministry'. The New Testament abounds with views on the positive place and role of the secular world (the state, 'all men', etc., cf. Barth 1960:109-131; Wright 2010:233-235).

One of the most vital issues in early Christianity was the concern for the poor, and the strong criticism of those who were rich, but did not care for the poor. Prominent church leaders such as Clement, Basil, Chrysostom and Augustine engaged in tireless efforts towards the poor, in search of a community where no one had too much and no one too little. Property was seen as a means toward self-sufficiency, but to hold possessions as a goal in itself was seen as robbing the poor, and an act of foolishness, since it would degenerate into a lifestyle of luxury that will be lived at the expense of the poor and will render the possessor worse off (Smith 2011:489-496).

This radical combination of faith and life played an important role in the rapid spread of the Christian faith in the early centuries. It also profoundly influenced Christian theology, especially through the important book of Augustine, The City of God. This book shows that the idea of a sustainable community builds on a long tradition in Christianity, even if the concept sustainability was not the main concept of this book, given the different context in which it was written.

Augustine (354-430) was one of the greatest theologians of Western Christianity. He started to write his influential work The City of God after the city of Rome was sacked by a Gothic army in 410. Rome was the symbol of a whole civilization. This is where the protection of the gods for the empire was made explicit. The Christians colluded with this myth, replacing the belief in the gods of the nations with the belief that Peter and Paul had travelled to Rome to lay their holy bodies in the city. Christians were as disillusioned with the sack of Rome as the non-Christians. The security of their civilized way of life was now destroyed. The City of God was written to defend Christianity against the contempt of the Roman philosophers that Christianity had no intellectual content. The sack of Rome focused the attention on the tension between finding security in an earthly empire and human achievements and finding security in God (Brown 1967:288-289, 312).

In The City of God, which consisted of 22 books, Augustine described the city of God and the city of humans in relational terms. All people strive for happiness; the difference is that some seek happiness in God and some seek happiness in themselves: '... the earthly city glories in itself, the Heavenly City glories in the Lord. The former looks for glory from men, the latter finds its highest glory in God' (Jenson 2006:15, 25). This kind of self-exaltation causes us to please ourselves and to be self-sufficient. This is done by individuals as well as communities. Augustine asserts the fundamentally social nature of the life of both cities, but the character of each city's sociality is different: 
Is it a harmonious, peaceful, worshipful society of persons united in relationship to God and one another, or is it a society of discord, war, private affections and broken relations? (Jenson 2006:9, 31)

These descriptions may sound utopian, but the seasoned journalist Henry Jeffreys (2014) recently compared the styles of former president Nelson Mandela and the present president of South Africa Jacob Zuma, in similar terms: Mandela's philosophy of life was simple: integrity, tolerance, decency, caring for your fellow humans, especially the most vulnerable ones, and reconciliation, even with your greatest enemy. But today we have an abundance of self-interest, obsession with power, greed and a hunger for corruption ${ }^{1}$. The result is that we have a different country from what we could have had, and was dreamt of in the time of Mandela.

It seems that the tradition of constructive and critical engagement of the church in the civil community was not maintained by the Reformation. In 1938, in his essay Rechfertigung und Recht (Justification and justice; translated as Church and State) Karl Barth (1960) embarked on an effort to fill a gap in the theology of the Reformers, namely that they did not set out what the:

inner and vital connection is between service of God in Christian living ... in the worship of the Church as such, and another form of service, which may be described as a 'political' service of God ... (pp. 101-102)

The 'political' service of God refers to the affairs of human justice and life in general. If there is no such inner connection, it would be possible to build a highly spiritual message and a very spiritual church that had ceased to seek or find any entrance into the sphere of these problems of human justice' - as has happened with Pietistic sterility. At the same time it would be possible to consider the question of human law very seriously and to construct a secular gospel of human law and a secular church - as has happened with the sterility of the Enlightenment. Barth (1960:104-105) blamed this separation, at least partly, on the gap in the Reformers' teaching, and he set out to correct it.

Barth sees the task of the state as that of maintaining order and justice; it is an important task in the coming of the Kingdom proclaimed by Jesus Christ:

the State belongs originally and ultimately to Jesus Christ; (that) in its comparatively independent substance, in its dignity, its function, and its purpose, it should serve the Person and the Work of Jesus Christ ... the State becomes 'demonic' not so much by an unwarrantable assumption of power - as is often assumed - but by the loss of its legitimate, relative independence, as by a renunciation of its true substance, dignity, function, and purpose ... (Barth 1960:118)

1.Jeffreys, $\mathrm{H}$. , in Beeld, 12.12 .2014 , Om in Madiba se spore te trap: 'Mandela se lewensfilosofie was nie geniaal nie. Dit was eintlik baie eenvoudig. Dit het op lewente vir jou medemens (veral die mees kwesbares) en versoening (selfs met jou grootste vyand). vyand).

Hoe moeilik is dít om na te volg? Wel, as ondinge soos eiebelang, magsbeheptheid, gierigheid en ' $n$ aptyt vir korrupte optrede ook in jou arsenaal is, is dit seker baie moeilik. En dít is waar ons grootste probleem lê met die navolging en uitleef van Mandela se erflating: Ons arsenaal is oorvloedig aan dié soort euwels.'
It is not inevitable that the State must become demonic. It can also play its intended role.

This view leads to a positive view of the role of the State: it must prevent chaos. Community life is seen as the arena where Christ must be served in the way that we live our secular lives.

Barth regarded both the Christian community, that is, the church who forms a community of people by reason of their knowledge of and belief in Jesus Christ, and the civil community, which is the commonality of people in a certain place, as part of the Kingdom of God, even if the civil community does not belief in that Kingdom. The civil community has shared interests, but no shared creed or conviction. The members of the church are also members of the civil community. The church forms the inner circle, with Christ in the centre, and the civil community the outer circle around the church (Barth 1960:150, 156).

This positive view of the role of the civil community means that the Christian will have high expectations of the state and the community. It makes the Christian more radical in its expectations of the state and other entities, and more consistent than others, but also more positive and more constructive (Herberg 1960:64).

The church's final loyalty is with the city built by God (Heb 11:10). It cannot give any present movement the same loyalty; the result is that no present ideology or civil community can be given absolute loyalty. This protects the Christian against fanaticism in politics. The Christian community joins the civil community in the search for the best form and most fitting system for each context (Barth 1960:160-161). It leads to a pragmatic and constructive, rather than an ideological involvement in politics and society.

The church must be involved in the matters of the community, and search for solutions that direct us towards the coming of the new heaven and earth that the church expects, where justice will reign. Barth (1960:154) points out that:

the object of the promise and the hope in which the Christian community has its eternal goal consists ... not in an eternal Church, but in the polis built by God and coming down from heaven to earth, and the nations shall walk in the light of it ...

Not only does the church see its future and its hope in the State that comes down from God, but the kings of the earth will bring their splendour into it (Rev 21:24):

And this city will not endure merely on the ruins of the annihilated glory of the peoples and kings of this earth, but the whole of his earthly glory will be brought into it, as supplementary tribute. (Barth 1960:124)

Wright agrees: the 'kings' are the bearers and representatives of their respective cultures:

... the promise spans all ages, all continents, and all generations in human history ... All human history, which takes place in the 
public square of human public interaction, will be redeemed and fulfilled in the new creation, not just abandoned. (Wright 2010:228-229)

This expectation is the logical conclusion of the message throughout the Bible, that God is taking all of creation and human history to its destination. The church and theology should not only be concerned with spiritual and religious matters, but with all of daily life. Theology should not only reflect on building up the church, but also on improving the quality of life of the community.

The State and the community, and the church, can also fail in their task. As Barth (1960:157) says: neither the civil nor the Christian communities are exempt from the possibility of perversion. The church, which should serve as the main agent in the search for life in its fullness for the community, a source of inspiration, of insight, of new energy, of dedication, can also become an organisation that is curved into itself. The church could become an institution without any interest in the needs and suffering of people outside its own ranks, and with no concern for the destructive impact we have on God's creation. Consisting of human beings, the church depends on God to give the gifts that bring life to us.

The community depends in many ways on the church, because as humans we cannot save ourselves. The civil community:

cannot call the human hybris into question fundamentally, and it knows of no final defence against the chaos which threatens it from that quarter; in this respect too, it depends on ultimate words and insights existing elsewhere. (Barth 1960:158)

The Christian community can play a role to prevent the civil community from being trapped in some or other destructive way of thinking and behaving, such as an ideology or the rampant consumer culture. The South African Council of Churches, for example, recently criticised the governing party for being too comfortable with 'wealth religion' (Hunter \& Mataboge 2014).

If the State fails in its mission and becomes evil itself, its failure does not take away its mission of being neutral in matters of truth and granting the Church freedom to proclaim the Gospel and that we may a live a peaceful life (1 Tim 2:2) (Barth 1960:119).

Barth was one of the first theologians to realise to what extend the optimism of the 19th century, the trust in the goodness of humans, and the expectation that human endeavour would bring salvation, which led to the general optimism of liberal theology, were shattered by the First World War. He wrote the above in 1938, after his active opposition to Nazi ideology had begun in 1934. In 1948, having lived through both the First and the Second World War, he expressed himself in still harsher terms. The State, he said, received from God the mission to do what is good and to prevent evil. Chaos is, however, always a real possibility because of human nature:
The Christian community knows of man's presumption and the plainly destructive consequences of man's presumption. It knows how dangerous man is and how endangered by himself. It knows him as a sinner, that is as a being who is always at the point of opening the sluices through which, if he were not checked in time, chaos and nothingness would break in and bring human time to an end. (Barth 1960:155)

Considering what have become of the high ideals that prevailed with the dawn of democracy in South Africa, we may tend to agree with Barth. Even more so if we consider, on a global level, the way in which science and technology have not only brought life but also the fear that our present economy may bring the world to ecological disaster. Our present ecological dilemmas are not as urgent as was the case with the Nazis, but they may be more chronic, more widely spread, less localised and clear-cut, and for that reason no less serious. These dilemmas confirm Barth's view that political questions are not only technical questions, but often questions in which 'spirits are tested' (Barth 1960:120; Herberg 1960:65).

Barth developed these ideas further in his Kirchliche Dogmatik, and emphasised that the church is there to live in solidarity with and responsibility for the world. Together with theologians such as Dietrich Bonhoeffer he became the main force behind the idea that the gospel of Jesus Christ is a message about how one should live in the world in a non-religious way, but with faith in God (Jonker 2008:59, 66-72).

\section{Conclusion}

The church must play its role as agent of life in its fullness in the secular sphere with dedication. Barth (with Dietrich Bonhoeffer) saw the secular sphere as the arena in which the Christian faith should find expression in a non-religious way, by promoting the wholeness and fullness of life. Barth accepted concepts of modern Western culture such as autonomy, freedom and change through activity (Jonker 2008:111, 112). However, it is important that the church also visibly and explicitly acts as a church. The importance of secular life does not mean that the role of the church can be reduced to addressing merely this-worldly suffering, or become an altogether faith-neutral affair. If the social organisations of the church offer services that do not differ from services offered by people who are not Christians, the church has not played its role as a church properly (cf. Delkeskamp-Hayes 2009:175.)

Barth, for example, always spoke as a theologian, and Barth's theology itself had a beneficial impact on European politics. His view of political activity as a 'free, direct approach to human beings and their welfare' is said to have contributed in Europe 'toward breaking down ideological politics in favour of a more pragmatic and practical approach to problems of state' (Herberg 1960:64-65, quoting Charles West).

Lastly, the church should position itself among those who focus on things such as justice, life and sustainability, 
rather than among the 'faith-based' communities, which is a category that has been defined by government and may relegate the church to purely religious matters.

\section{Acknowledgements Competing interests}

The author declares that he has no financial or personal relationships which may have inappropriately influenced him in writing this article.

\section{References}

Algemene Sinode, 2013, 'Raamwerkdokument oor die missionale aard en roeping van die NG Kerk, Oorkoepelende verslag', finale kopie (2), Pretoria, viewed n.d., from http://ngkerk.org.za/AS2013/wp-content/uploads/2013/09/A.12.7-MISSIONALEAARD-EN-ROEPING-VAN-DIE-NG-KERK.pdf

Balia, D. \& Kim, K. (eds.), 2010, Witnessing to Christ today, Regnum Books International, Oxford.

Barth, K., 1960, Community, state and church. Three essays by Karl Barth, Anchor Books, New York.

Benedict XVI, 2009, Caritas in veritate, Libreria Editrice Vaticana, viewed n.d., from http://w2.vatican.va/content/benedict-xvi/en/encyclicals/documents/hf_benxvi_enc_20090629_caritas-in-veritate.html

Brown, P., 1967, Augustine of Hippo, Faber \& Faber, London.

Degrees in Environmental \& Geographical Science, University of Cape Town, viewed 04 August 2015, from http://www.egs.uct.ac.za/degree.html
Delkeskamp-Hayes, C., 2009, 'Diakonia, the state, and ecumenical collaboration: Theological pitfalls', Christian Bioethics, 15(2), 173-198. http://dx.doi. Theological pitfalls, ${ }^{\prime}$,
org $/ 10.1093 / \mathrm{cb} / \mathrm{cbp013}$

Franciscus, 2015, Laudato $\mathrm{Si}^{\prime}$, On care for our common home, Libreria Editrice Vaticana, viewed n.d., from http://w2.vatican.va/content/francesco/en/ encyclicals/documents/papa-francesco_20150524_enciclica-laudato-si.pdf

Franks, D.M., Davis, R., Bebbington, A.J., Alia, S.H., Kemp, D. \& Martin, S., 2014, 'Conflict translates environmental and social risk into business costs', Proceedings of the National Academy of Sciences, 111(21), 7576-7581. http://dx.doi. org/10.1073/pnas.1405135111

Herberg, W., 1960, The social philosophy of Karl Barth (Introduction to: Community, State and church. Three essays by Karl Barth), Anchor Books, New York.

Hunter, Q. \& Mataboge, M., 2014, 'Why churches dumped the ANC', Mail and Guardian, 23 December, n.p.

Jeffreys, H., 2014, 'Om in Madiba se spore te trap', Beeld, 12 December, n.p.

Jenson, M., 2006, The gravity of sin. Augustine, Luther and Barth on homo incurvatus in se, T\&T Clark, New York.

Jonker, W.D., 2008, Die relevansie van die kerk, Bybel-media, Wellington.

Rasmussen, L.L., 1996, Earth community, earth ethics, WCC Publications, Geneva.

Smith, T.J., 2011, 'A dialogue about the South African "here and now" with the legacies of the early church fathers as interlocutors', Nederduitse Gereformeerde Teologiese Tydskrif 52(3\&4), 489-496.

South African Council of Churches, 2009, Climate change-A challenge to the churches in South Africa, SACC Declaration, Marshalltown.

World Council of Churches, 2013, Resource Book, World Council of Churches 10th Assembly Busan, 2013, WCC Publications, Geneva.

Wright, C.J.H., 2010, The mission of God's People. A biblical theology of the church's mission, Zondervan, Grand Rapids.

Zhuwakinyu, M. (ed.), 2013, 'CSMI stresses role of research to ensure policy, laws and practice support sustainable mining', Mining weekly, 13 December, viewed 14 February 2015, from http://www.miningweekly.com/article/csmi-boostsresearch-plans-for-2014-2013-12-13 